\title{
Commentary: How Cells Can Control Their Size by Pumping lons
}

\author{
Igor A. Vereninov ${ }^{1}$, Valentina E. Yurinskaya ${ }^{2}$ and Alexey A. Vereninov ${ }^{2 *}$ \\ ${ }^{1}$ Saint Petersburg State Polytechnic University, Saint Petersburg, Russia, ${ }^{2}$ Institute of Cytology (RAS), Saint Petersburg, \\ Russia
}

Keywords: cell water regulation, impermeant anions, ion transport, potassium, chloride channels, chloride exchangers, sodium-hydrogen exchanger

\section{A commentary on}

How Cells Can Control Their Size by Pumping Ions

by Kay, A. R. (2017). Front. Cell Dev. Biol. 5:41. doi: 10.3389/fcell.2017.00041

\section{OPEN ACCESS}

Edited by:

Eiman Aleem,

Phoenix Children's Hospital, University

of Arizona College of

Medicine-Phoenix, United States

Reviewed by:

Ignacio Gimenez,

Aragon's Health Sciences Institute,

Spain

*Correspondence:

Alexey A. Vereninov

verenino@gmail.com

Specialty section

This article was submitted to

Cell Growth and Division,

a section of the journa

Frontiers in Cell and Developmental

Biology

Received: 23 May 2017

Accepted: 04 August 2017

Published: 21 August 2017

Citation:

Vereninov IA, Yurinskaya VE and Vereninov AA (2017) Commentary: How Cells Can Control Their Size by

Pumping lons.

Front. Cell Dev. Biol. 5:72

doi: $10.3389 /$ fcell.2017.00072
Intracellular water typically occupies about $80 \%$ of the total cell volume. The very important theoretical article by Alan Kay calls attention to the roles of impermeant intracellular osmolytes and ion pumping in the regulation of cell water. Theoretical predictions presented by A. Kay agree with available experimental data. In our study of U937 cells going into apoptosis (Yurinskaya et al., 2011), only $56-72 \%$ of the observed volume loss could be explained by the efflux of monovalent ions; a significant portion of the lost osmolytes must have been the "impermeant intracellular anions." No pumping of chloride was assumed in the calculations presented by Kay. In our opinion, this is a significant shortcoming of the model because the role of chloride channels and transporters in cell water and chloride regulation has been proved beyond doubt (Hoffmann et al., 2009, 2015; Voipio et al., 2014). Our recent studies show how the major chloride co- and countertransporters and channels can determine chloride disequilibrium distribution across the membrane and the electrochemical potential differences under various conditions (Vereninov et al., 2014, 2016). We have developed a computational software to determine the fluxes of monovalent ions in cells of various kinds, with membrane potentials from -5 to $-90 \mathrm{mV}$ and the intracellular $\mathrm{K}^{+} / \mathrm{Na}^{+}$ratios between 0.2 and 9 , i.e., for the entire range of values encountered in real animal cells. The modeling of cell water balance as a function of various transport rates shows, in particular, that the coupled operation of $\mathrm{Na} / \mathrm{H}$ and $\mathrm{Cl} / \mathrm{HCO}_{3}$ exchangers and chloride channels are much more powerful regulators of water balance than NKCC, KCC cotransporters, or the Na/K ATPase pump. The role of $\mathrm{Na} / \mathrm{H}$ and $\mathrm{Cl} / \mathrm{HCO}_{3}$ exchangers should be stressed especially. It is known since the1980th (see e.g., Grinstein et al., 1988). Lew was the first who includes Na-Cl cotransport in the calculation of the flux balance in cells. Lew stressed that "reticulocytes, unlike mature RBCs, need $\mathrm{Na}^{+}$-dependent anion influx transporters to maintain volume stability" (Lew et al., 1991, p. 105). Our computation of the monovalent ion flux balance was performed assuming the values of rate coefficients obtained on proliferating human lymphoid cells U937, which may serve as a prototype of cells with intermediate values of the membrane potential and of the $\mathrm{K}^{+} / \mathrm{Na}^{+}$ ratio. The computational modeling showed that it is the rate of $\mathrm{Cl}^{-}$gain that determines the kinetics of cell ion and water changes caused by blocking the $\mathrm{Na} / \mathrm{K}$ ATPase pump and that the rate of $\mathrm{Cl}^{-}$redistribution may be very slow in spite of the fast $\mathrm{Cl}^{-} / \mathrm{Cl}^{-}$exchange. As a result, the disturbance caused by the $\mathrm{Na} / \mathrm{K}$ pump inhibition may initially proceed as a nearly equivalent exchange of $\mathrm{K}^{+}$for $\mathrm{Na}^{+}$with no cell swelling. This computational prediction was fully confirmed in experiments with U937 cells. 


\section{AUTHOR CONTRIBUTIONS}

All authors listed have made a substantial, direct and intellectual contribution to the work, and approved it for publication.

\section{REFERENCES}

Grinstein, S., Garcia-Soto, J., and Mason, M. J. (1988). Proton passage across cell membranes. Ciba Found. Symp. 139, 70-90.

Hoffmann, E. K., Belinda, H., Sørensen, B. H., Sauter, D. P., and Lambert, I. H. (2015). Role of volume-regulated and calcium-activated anion channels in cell volume homeostasis, cancer and drug resistance. Channels 9, 380-396. doi: 10.1080/19336950.2015.1089007

Hoffmann, E. K., Lambert, I. H., and Pedersen, S. F. (2009). Physiology of cell volume regulation in vertebrates. Physiol. Rev. 89, 193-277. doi: 10.1152/physrev.00037.2007

Lew, V. L., Freeman, C. J., Ortiz, O. E., and Bookchin, R. M. (1991). A mathematical model of the volume, $\mathrm{pH}$, and ion content regulation in reticulocytes. Application to the pathophysiology of sickle cell dehydration. J. Clin. Invest. 87, 100-112.

Vereninov, I. A., Yurinskaya, V. E., Model, M. A., Lang, F., and Vereninov, A. A. (2014). Computation of pump-leak flux balance in animal cells. Cell. Physiol.Biochem. 34, 1812-1823, doi: 10.1159/000366382

Vereninov, I. A., Yurinskaya, V. E., Model, M. A., and Vereninov, A. A. (2016). Unidirectional flux balance of monovalent ions in cells with $\mathrm{Na} / \mathrm{Na}$ and $\mathrm{Li} / \mathrm{Na}$

\section{FUNDING}

This work was supported by the RFBR grants no. 15-04-00776a and no. 17-00-00364 KOMFI.

exchange: experimental and computational studies on lymphoid U937 cells. PLoS ONE 11:e0153284. doi: 10.1371/journal.pone.0153284

Voipio, J., Boron, W. F., Jones, S. W., Hopfer, U., Payne, J. A., and Kaila, K. (2014). Comment on "Local impermeant anions establish the neuronal chloride concentration.” Science 345:1130. doi: 10.1126/science. 1252978

Yurinskaya, V. E., Rubashkin, A. A., and Vereninov, A. A. (2011). Balance of unidirectional monovalent ion fluxes in cells undergoing apoptosis: why does $\mathrm{Na}^{+} / \mathrm{K}^{+}$pump suppression not cause cell swelling? J. Physiol. (Lond.) 589(Pt 9), 2197-2211. doi: 10.1113/jphysiol.2011.207571

Conflict of Interest Statement: The authors declare that the research was conducted in the absence of any commercial or financial relationships that could be construed as a potential conflict of interest.

Copyright (c) 2017 Vereninov, Yurinskaya and Vereninov. This is an open-access article distributed under the terms of the Creative Commons Attribution License (CC $B Y)$. The use, distribution or reproduction in other forums is permitted, provided the original author(s) or licensor are credited and that the original publication in this journal is cited, in accordance with accepted academic practice. No use, distribution or reproduction is permitted which does not comply with these terms. 